\title{
STRATEGI PEMBELAJARAN PENDIDIKAN LUAR SEKOLAH
}

\author{
Bertha Bintari Wahyujati*
}

\begin{abstract}
Instructional strategy is one of important factors to achieve instructional objectives. The instructional strategy developed for a teaching and learning situation will be effective if instructional methods and models are appropriately selected. This article discusses some considerations upon the selection of appopriate instructional strategies and describes a case study in life skills training. The case proves the significant role of appropriate instructional strategies in achieving training objectives.
\end{abstract}

Key words: instructional strategy, life skills, instructional models

\section{PENDAHULUAN}

Kompetisi di bidang ketenagakerjaan semakin kompetitif terutama setelah dibukanya gerbang AFTA dan APEC sehingga calon pencari kerja di dalam negeri semakin ketat bersaing dengan pesaing-pesaing calon tenaga kerja dari negara-negara lain, termasuk dari negara-negara tetangga.

Perubahan paradigma bisnis di Indonesia dengan dibukanya perdagangan bebas ASEAN tersebut menyebabkan perubahan pada tuntutan terhadap tenaga kerja atau sumber daya manusia, sistem kerja, struktur tenaga kerja, persyaratan kerja dan permintaan kerja, baik dari segi kuantitas maupun kualitasnya. Diversifikasi pekerjaan menuntut pula keahlian profesional dalam bidang masing-masing bagi sumber daya manusia. Keahlian profesional, peningkatan kualitas, kuantitas, relevansi dan produktivitas sumber daya manusia hanya dapat diperoleh melalui pendidikan.

Pendidikan merupakan faktor penting dalam mendukung kebutuhan sumber daya manusia yang terlatih dan terdidik untuk menunjang perkembangan dan perubahan struktur ekonomi di dalam negeri. Pendidikan baik di sekolah maupun luar sekolah perlu disesuaikan dengan perkembangan dan tuntutan zaman. Penyesuaian diri suatu lembaga pembelajaran adalah dengan melakukan suatu perencanaan inovasi. Perencanaan inovasi dapat diartikan sebagai proses perencanaan yang menitikberatkan pada kegiatan untuk menumbuhkan perubahan fungsi dan wawasan kelembagaan dalam memecahkan masalah yang menyangkut kehidupan masyarakat. Dengan demikian lembaga pembelajaran yang telah melakukan perencanaan inovasi dapat menyelenggarakan suatu jenis pembelajaran yang sesuai dengan kebutuhan dalam masyarakat.

\section{* LPMK VISTA STIMKY, Bantul, Yogyakarta}

Latar belakang ekonomi yang diperburuk dengan kondisi terpuruknya Perekonomian nasional menyebabkan angka pengangguran semakin tinggi. Data Departemen Tenaga Kerja dan Transmigrasi menunjukkan angka pengangguran pada tahun 2002 sebesar $8,22 \%$ untuk lulusan diploma, dan 22,21\% untuk lulusan S1, sedangkan pada tahun 2003 angka tersebut meningkat 10,1\% untuk lulusan diploma dan $30,73 \%$ untuk lulusan S1. Berdasarkan data tersebut dapat disimpulkan bahwa tenaga kerja yang terdidik (dari tingkat menengah sampai S1) belum mampu memberdayagunakan kemampuan atau pendidikan yang mereka peroleh.

Dengan pertimbangan penghematan biaya tenaga kerja maka saat ini dunia industri cenderung lebih memilih mencari tenaga kerja lulusan pendidikan menengah yang secara langsung telah dibekali dengan ketrampilan khusus sehingga dapat meningkatkan produktifitas kerjanya tanpa mengeluarkan biaya gaji yang terlalu besar. Oleh karena itu diperlukan suatu pendidikan yang mampu memberikan ketrampilan khusus bagi lulusannya sehingga mereka langsung dapat terserap di dunia kerja dan siap bekerja. Dari kondisi tersebut, pendidikan luar sekolah memegang peranan untuk memfasilitasi pendidikan masyarakat melalui pelatihan, kursus, ataupun magang yang akan berlangsung berhubungan dengan pemenuhan kecakapan hidup (life skill) sehingga para peserta didik mampu memberdayagunakan diri, mandiri dan dapat meningkatkan taraf hidupnya.

Menurut Keputusan Menteri Tenaga Kerja No. 1331 Tahun 1987 tentang Pola Umum Pembinaan Sistem Latihan Kerja telah dijelaskan bahwa dalam pelaksanaan pelatihan kerja baik yang dilaksanakan oleh lembaga pemerintah (BLK) maupun non pemerintah seperti kursus-kursus atau lembaga pelatihan kerja swasta maka program tersebut harus: 
1. sesuai dengan permintaan yang ada dalam pasar kerja;

2. senantiasa mengikuti perkembangan ilmu pengetahuan dan teknologi; dan 3) merupakan kegiatan pelatihan yang memiliki sifat keterpaduan baik proses maupun implementasinya.

Pendidikan dengan prinsip meningkatkan kemampuan dan penguasaan kecakapan hidup mencakup hal-hal berikut.

1. Kecakapan personal (personal skill) yang mencakup kecakapan mengenal diri (self awareness) dan kecakapan berpikir rasional (thinking skill). Kecakapan diri ini meliputi penghayatan diri sebagai mahluk Tuhan Yang Maha Esa, anggota masyarakat dan negara, serta menyadari dan mensyukuri kelebihan dan kekurangan yang dimiliki sekaligus menjadikannya modal dalam dirinya sebagai individu yang bermanfaat bagi dirinya sendiri dan lingkungannya.

2. Kecakapan berfikir rasional (thinking skill) meliputi: (1) kecakapan menggali dan menemukan informasi (information searching), (2) kecakapan mengolah informasi dan mengambil keputusan (information processing and decision making skill), serta (3) kecakapan memecahkan masalah secara kreatif ( creative problem solving skill).

3. Kecakapan sosial (social skill) mencakup: (1) kecakapan komunikasi dengan empati (communication skill) dan (2) kecakapan bekerjasama (collaboration skill). Berempati merupakan sikap penuh pengertian dan seni komunikasi dua arah, perlu ditekankan karena yang dimaksud berkomunikasi bukan sekedar menyampaikan informasi, pesan, tetapi isi dan sampainya pesan disertai kesan balik yang dapat menumbuhkan hubungan yang harmonis.

4. Kecakapan akademik (academic skill) sering kali disebut sebagai kemampuan berpikir ilmiah (scientific method), mencakup kemampuan untuk melakukan: (1) identifikasi variabel, (2) merumuskan hipotesis, dan (3) melaksanakan penelitian.

5. Kecakapan vokasional atau keterampilan kejuruan (vocational skill) adalah keterampilan yang dikaitkan dengan pekerjaan tertentu yang berguna untuk hidup dan dalam kehidupannya. Artinya dengan keterampilan kerja tersebut seseorang dapat menghasilkan pendapatan dari usaha wiraswasta yang dilakukannya sendiri. Kecakapan nomor satu dan dua adalah kecakapan umum (general life skill) dan harus dimiliki oleh semua orang yang telah menempuh suatu jenjang pendidikan. Sedangkan kecakapan akademik dan kecakapan vokasional disebut sebagai kecakapan hidup yang bersifat spesifik yaitu kecakapan untuk menghadapi problem tertentu yang bersifat teknis yang secara langsung terkait dengan metode dan isi dari pelatihan yang dirancang untuk membentuk keahlian tertentu sesuai dengan tujuannya.

Prinsip dari pelatihan untuk penguasaan kecakapan hidup antara lain adalah akses pembelajaran melalui prinsip learning to do, learning to be, dan learning to life together (Ditjen Diklusepa, 2003; 7) dan mengambil dasar paradigma learning for life and school to work menjadi kebijakan nasional yang pada hakekatnya adalah upaya meningkatkan keterampilan, pengetahuan, sikap, dan kemampuan yang memungkinkan warga belajar dapat hidup mandiri Pelaksanaan program kecakapan hidup (life skill) diarahkan untuk memperkuat kecakapan akademik dan kecakapan vokasional serta meningkatkan kecakapan general life skill. Dengan demikian maka pendidikan kecakapan hidup menerapkan kurikulum berbasis kompetensi. Sedangkan kompetensi yang hendak dicapai adalah sebagai berikut.

\section{Kompetensi Generik (Generic Competency) \\ Kompetensi generik adalah kecakapan umum} yang harus dikuasai oleh semua peserta didik yaitu terdiri dari dua kompetensi: (1) kompetensi kunci (key competency) dan (2) kompetensi dasar (basic competency). Kompetensi kunci sebagai kompetensi kehidupan meliputi: (a) keterampilan dasar yang kuat dan luas sehingga memungkinkan pengembangan sesuai dengan pengembangan ilmu pengetahuan dan teknologi (IPTEK); (b) kecakapan mengumpulkan, menganalisis, menggunakan data; (c) kecakapan mengkomunikasikan ide dan informasi; (d) kecakapan merencanakan dan mengorganisasikan kegiatan; (e) kecakapan memecahkan masalah; (f) kecakapan berfikir logis dan menggunakan teknik-teknik matematika; dan (g) menguasai bahasa komunikasi.

\section{Kompetensi Khusus (Specific Life Skill)}

Kompetensi ini terkait dengan bidang program keahlian yang dimiliki oleh peserta didik. untuk 
memenuhi tuntutan lapangan pekerjaan tetapi juga mempunyai kemampuan berpikir konseptual untuk mobilitas mengikuti dinamika pasar kerja.

Selain kompetensi tersebut keunggulan daya saing sumber daya manusia juga ditentukan dari pengembangan soft skill yang dimiliki. Soft skill meliputi hal-hal berikut.

a. Psychological skill (kecakapan psikologis): mempunyai kepercayaan diri, rasa harga diri, disiplin diri, bertindak sopan, kemampuan belajar dan diajar, mampu memotivasi orang lain, mampu bekerja dengan dan di bawah suatu sistem, mampu memanfaatkan informasi, kepemimpinan, dan mengerti budaya dan etika.

b. Conceptual skill (kecakapan konseptual): memiliki pemikiran kreatif, produktif, kemampuan menganalisis, logika berpikir, kritis, menyimpulkan dan mencari alternatif pemecahan masalah. Serta merencanakan dan mengorganisir kegiatan.

c. Kecakapan berkomunikasi: kemampuan menyampaikan, menyalurkan ide secara tertulis, oral, dan komunikasi non verbal, kemampuan mendengarkan penuh perhatian,

d. Kecakapan sosial: kemampuan bekerja dalam teamwork, kooperatif, toleran, mampu mengelola dan menangani konflik dan berbagi ide dengan team.

Dengan memiliki kemampuan soft skill ini sumber daya manusia akan mampu dengan cepat beradaptasi dan akan siap terjun di dunia kerja.

\section{KAJIAN TEORI}

Pembelajaran merupakan proses yang meliputi mengajar dan belajar. Belajar adalah proses mengkonstruksi pengetahuan dan abstraksi pengalaman baik alami maupun manusiawi. Proses konstruksi itu dilakukan secara pribadi dan sosial. Proses ini adalah proses yang aktif. Beberapa faktor seperti pengalaman, pengetahuan, kemampuan kognitif, dan lingkungan berpengaruh terhadap hasil belajar. Sedangkan mengajar adalah proses membantu seseorang untuk membentuk pengetahuannya sendiri dengan menkonstruksi pengetahuan melalui fenomena dan obyek yang dialami. Melalui pengalaman inilah peserta didik dapat mencapai tujuan belajar atau memperoleh suatu keahlian tertentu dari proses pembelajaran. Proses pembelajaran yang sistematis dan terarah diharapkan mampu mencapai hasil yang sesuai dengan tujuan pembelajaran.

Pelatihan adalah salah satu bentuk pembelajaran karena mengandung pengertian sebagai proses mengembangkan bakat, keterampilan, dan kemampuan SDM dalam menyelesaikan pekerjaanpekerjaan tertentu. Sedangkan tujuan pelatihan adalah untuk menambah pengetahuan, keterampilan,dan perbaikan sikap dari peserta pelatihan. Model pelatihan yang sesuai dengan karakteristik orang dewasa adalah metode pendekatan partisipasi andragogi. Metode pelatihan yang efektif adalah metode pelatihan yang berbasis lapangan dengan menggunakan model pembelajaran daur pengalaman berstruktur dan metode analisis ATMAP (Arah, Terapan, Masalah, Alternatif dan Peran) tahap-tahap dalam model pembelajaran daur pengalam-an berstruktur adalah:
(1) pengenalan dan penghayatan terhadap masalah,

(2) pengungkapan masalah,

(3) pengolahan masalah,

(4) penyimpulan dan cara memecahkan masalah, dan

(5) penyerapan dan penerapan cara-cara pemecahan masalah.

Proses pembelajaran dalam tulisan ini mengambil suatu studi kasus pada pembelajaran penguasaan kecakapan hidup dengan pendidikan luar sekolah, yang bertujuan bahwa peserta didik secara formal telah memiliki kecakapan akademik namun masih memerlukan peningkatan ketrampilan khusus atau spesifik dengan bidang keahlian tertentu. Dengan peningkatan keterampilan spesifik tersebut, peserta didik diharapkan mampu memberdayagunakan diri, mandiri, memiliki kualitas daya saing pada bidangnya. Oleh karena itu pemilihan model pembelajaran yang tepat akan mendukung proses pembelajaran tersebut.

Model pembelajaran adalah kerangka konseptual yang melukiskan prosedur yang sistematis dalam mengorganisasikan pengalaman belajar untuk mencapai tujuan tertentu dan berfungsi sebagai pedoman bagi perancang pembelajaran dan para pengajar dalam merencanakan dan melaksanakan aktivitas belajar mengajar.

Sebagai perbandingan dan pemilihan model pembelajaran, berikut adalah rangkuman mengenai ciriciri utama dari empat model belajar mengajar yaitu:

1. model pengolahan informasi dengan orientasi pokok pada proses kognitif, pemahaman dunia, pemecahan masalah dan berpikir induktif; 
2. model personal dengan orientasi pokok pada kesadaran individu, keunikan personal, kemandirian, dan pembinaan kepribadian;

3. model sosial dengan orientasi pokok semangat kelompok, kebersamaan, interaksi social serta individu sebagi aktor sosial; dan

4. model sistem perilaku dengan orientasi pokok pada social learning, koreksi diri, terapi perilaku, dan respon terhadap tugas.

Model pembelajaran yang umum digunakan adalah: (1) model pengorganisasian pertemuan yang digunakan dalam situasi proses komunikasi melalui pertemuan umum dan situasi interaksi pembelajaran formal dan (2) model diskusi kelompok digunakan dalam situasi interaksi pembelajaran kelompok secara bervariasi.

Model pembelajaran dengan model pengorganisasian pertemuan dapat berbentuk sidang umum, sidang pleno, kerja kelompok, kelompok minat khusus, forum, penyajian situasi, penyajian konflik, penyajian skill, presentasi film, presentasi visual, symposium, panel. Kelompok okupasi, kelompok aplikasi, kelompok orientasi, kelompok khusus, konvensi, konferensi kerja, lokakarya, seminar, klinik, dan institut.

Sedangkan model pembelajaran dengan model diskusi kelompok memiliki bentuk: model brainstroming group, model kelompok bebas, model studi kasus, model kelompok silang pendapat, model diskusi kelompok bebas, model kelompok tapal kuda model terpusat pada masalah, model bermain peran, model seminar group, model simulasi model kelompok singkat, kelompok terapetik, dan model tutorial.

Pemilihan model belajar yang efektif sebenarnya adalah melakukan strategi belajar mengajar. Strategi belajar mengajar merupakan siasat atau keseluruhan aktivitas yang dilakukan guru/ instruktur untuk menciptakan suasana belajar mengajar yang sangat kondusif guna tercapainya tujuan pendidikan. Strategi akan menghubungkan sumber daya manusia dengan sumber daya lain dengan tantangan dan resiko yang dihadapi dari lingkungan luar. Proses pembelajaran bagi sumber daya manusia yang mempunyai penguasaan kecakapan hidup berbasis pada kompetensi memerlukan suatu perencanaan dan strategi yang tepat sehingga materi yang disampaikan benar- benar tepat sasaran dan mampu dimanfaatkan peserta didik untuk mandiri serta meningkatkan taraf hidupnya, dan mempunyai kualitas yang berdaya saing

Dengan rencana stategis yang tepat akan menjadi faktor yang mampu menjadi kompetitor terhadap pesaing, dalam hal ini sumber daya manusia dari dalam maupun luar negeri.

Secara teori terdapat beberapa macam model pembelajaran yang dapat diterapkan. Namun sebagai seorang pengajar dituntut dapat memilih suatu model pembelajaran sebagai suatu strategi yang efektif. Terdapat lima faktor yang menentukan efektivitas mengajar para pengajar yaitu:

1. ekspektasi pengajar tentang kemampuan pembelajar yang akan dikembangkan,

2. keterampilan pengajar dalam mengelola kelas,

3. jumlah waktu yang digunakan oleh pembelajar untuk melakukan tugas-tugas belajar yang bersifat akademis,

4. kemampuan pengajar dalam mengambil keputusan pembelajaran, dan

5. variasi metode mengajar yang dipakai oleh pengajar. Secara umum strategi belajar mengajar dapat dikategorikan dalam dua kelompok strategi, yaitu:

a. strategi yang diarahkan pengajar dengan cara ceramah, tanya jawab, dan latihan; serta

b. strategi yang terpusat pada pembelajar antara lain dengan belajar kelompok, dan penemuan yang didampingi (Guided Discovery). (Soekamto \& Winataputra,1994)

Permasalahan yang dihadapi oleh para pengelola pembelajaran terutama pembelajaran di luar sekolah adalah menetapkan suatu strategi pembelajaran yang efektif sehingga kualitas lulusan mempunyai daya saing dalam dunia kerja.

pelatihan adalah untuk menambah pengetahuan, keterampilan,dan perbaikan sikap dari peserta pelatihan.

\section{Studi kasus}

Proses pembelajaran dalam studi kasus ini dilakukan melalui program pendidikan khusus yaitu program perencanaan dan perancangan bangunan selama satu tahun. Program pendidikan ini berdasar pada program penguasaaan kecakapan hidup yang berbasis kompetensi khusus program perencanaan dan pematangan bangun/bangunan tersebut dipilih sebagai program pendidikan angka pendek yang memberikan semacam pelatihan di bidang bangunan dikarenakan bidang tersebut masih mampu menciptakan banyak peluang dan kesempatan kerja bagi peserta lulusannya. Sumber daya yang dibutuhkan oleh perusahaan yang bergerak di bidang bangunan selain arsitek, perencana sipil, estimator adalah drafter yang terlatih dan memiliki dasar pengetahuan, 
membaca, menghitung anggaran, menggambar teknis serta berpengalaman. Selain itu sumber daya yang telah terlatih akan mampu menciptakan kesempatan kerja bagi orang lain dengan berwirausaha sendiri.

Kompetensi khusus tersebut adalah mencapai target untuk peserta didik mampu minimal menjadi drafter bangunan yang mengetahui seluk beluk dan unsur bangunan, menjadi leveransir, estimator, pembuat maket (rancang) sampai memiliki kemampuan sebagai pemborong bangunan. Keterampilan dan kecakapan hidup yang dijadikan tujuan dalam pelatihan tersebut diharapkan mampu meningkatkan kompetensi peserta didik yang telah mendapatkan dasar-dasar mengenai bangunan dan proses bangunan namun belum memiliki dasar-dasar teknik, metode, analisis dalam perancangan dan perencanaan bangunan yang sistematis. Peserta didik yang mengikuti program tersebut lebih diarahkan pada peserta didik Iulusan SMU atau SMK jurusan bangunan dan gambar bangunan.

Program tersebut dirancang dengan mengambil teknik dan metode perancangan sistematis yang praktikal dan berdasarkan pengalaman di lapangan. Metode pembelajaran adalah $30 \%$ teori dan $70 \%$ praktek. Instruktur lebih mengarahkan pada permasalahan nyata di lapangan melalui penghayatan dan pengenalan masalah, pengungkapan masalah, pengolahan masalah, penyimpulan masalah, pemecahan masalah, dan penerapan cara pemecahan masalah adalah permasalahan nyata di lapangan.

Program disusun dalam 3 (tiga) periode atau catur wulan, Alokasi waktu adalah 1 jam pertemuan adalah 90 menit. Masing-masing materi dilakukan dengan pertemuan selama 14 kali. Materi ajar saling berkaitan sebagai satu kesatuan yang dipraktekkan peserta didik dalam studio perancangan, sebagai tugas besar yang pada akhirnya peserta didik dilatih untuk mebuat perencanaan dan perancangan proyek pribadi dengan studi kasus bangunan-bangunan tertentu sebagai tugas akhir penentuan kelulusan peserta didik. Penentuan kelulusan dilakukan dengan pengujian dan instruktur dan pelaku bisnis bangunan misalnya konsultan dan kontraktor yang diundang. Kurikulum disusun berdasarkan materi yang berguna langsung di lapangan. Kurikulum tersebut adalah sebagai berikut.

Tabel 1. Catur wulan I

\begin{tabular}{|c|l|c|}
\hline No & \multicolumn{1}{|c|}{ Mata Ajar } & Alokasi Waktu \\
\hline 1. & Studio Rancang Bangun I & $\left(4 \times 90^{\prime}\right)$ \\
\hline 2 & Perencanaan bangunan I & $\left(2 \times 90^{\prime}\right)$ \\
\hline 3 & Pengantar Komputer & $\left(2 \times 90^{\prime}\right)$ \\
\hline 4 & Komunikasi CAD I (AutoCad) & $\left(4 \times 90^{\prime}\right)$ \\
\hline 5 & Struktur dan Konstruksi Bangunan 1 & $\left(2 \times 90^{\prime}\right)$ \\
\hline 6 & Gambar Teknik & $\left(3 \times 90^{\prime}\right)$ \\
\hline & Jumlah & $\left(17 \times 90^{\prime}\right)$ \\
\hline
\end{tabular}

Tabel 2. Catur wulan 2

\begin{tabular}{|c|l|c|}
\hline No & \multicolumn{1}{|c|}{ Mata Ajar } & Alokasi Waktu \\
\hline 1. & Studio Rancang Bangun H & $\left(4 \times 90^{\prime}\right)$ \\
\hline 2 & Perencanaan bangunan II & $\left(2 \times 90^{\prime}\right)$ \\
\hline 3 & Komunikasi CAD II (AutoCad) & $\left(4 \times 90^{\prime}\right)$ \\
\hline 4 & Struktur dan Konstruksi Bangunan I & $\left(2 \times 90^{\prime}\right)$ \\
\hline 5 & Utilitas Bangunan & $\left(2 \times 90^{\prime}\right)$ \\
\hline 6 & Manajemen Proyek & $\left(2 \times 90^{\prime}\right)$ \\
\hline 7 & Interior & $\left(2 \times 90^{\prime}\right)$ \\
\hline & Jumlah & $\left(18 \times 90^{\prime}\right)$ \\
\hline
\end{tabular}

\section{Catur wulan 3}

Studio Tugas Akhir. Dalam studio tugas akhir peserta didik secara mandiri dan individu mengerjakan suatu tugas proyek bangunan tertentu mulai dari konsep prarancangan sampai pada hasil akhir berupa gambar kerja dan maket bangunan.

Pokok bahasan dalam mata ajar studio rancang bangun adalah teknik merencanakan dan merancang gambar bangunan, teknik presentasi gambar dan studi bentuk, dan teknik pembuatan maket. Tujuan instruksionalnya adalah peserta didik mampu merencanakan dan merancang, mempresentasikan dan membuat maket bangunan serta mengerjakan tugas perancangan lengkap dengan gambar kerjanya dalam waktu yang ditentukan.

Pokok bahasan materi ajar perencanaan dan perancangan bangunan adalah perencanaan untuk perancangan yang sistematis melalui proses konsep prarancangan, mengerti mendiskripsikan proyek, tujuan dan sasaran serta penekanan desain, kemudian melakukan analisa terhadap faktor-faktor yang berpengaruh dan mempengaruhi rancangan berupa analisa mikro dan makro, kemudian melakukan studi pendenahan untuk rancangan.

Pokok bahasan materi ajar gambar teknik adalah memahami membaca gambar, mulai dari gambar kerja, gambar dua dimensi menjadi gambar tiga dimensi, teknis proyeksi, menggunakan metode pengukuran skalatis, penggunaan standar notasi, pembuatan dan teknik menggambar gambar kerja secara manual.

Pokok bahasan materi ajar Komunikasi CAD (Auto $\mathrm{Cad}$ ) adalah pengenalan dan pemahaman serta penggunaan aplikasi program autocad untuk penggambaran gambar kerja sesuai standar profesional.

Pokok bahasan materi ajar struktur dan konstruksi bangunan adalah pemahaman tentang berbagai macam unsur bangunan, teknis dan struktural bangunan, pengawasan proyek di lapangan, aplikasi gambar kerja dengan bahan atau material serta sistem kerja pekerja di lapangan.

Pokok bahasan materi ajar utilitas bangunan adalah pemahaman mengenai utilitas dalam bangunan 
yang harus direncanakan, serta perencanaan gambar kerja utilitas.

Pokok bahasan materi ajar interior adalah pengenalan dan pemahaman serta keterampilan merancang tata letak ruang dalam melalui teknik proyeksi maupun gambar kerja, memahami material yang berkaitan dengan furniture, serta hal-hal yang berkaitan dengan teknik menata ruang dalam. Pokok bahasan materi ajar manajemen proyek bangunan adalah memahami unsur-unsur yang terlibat dalam pengelolaan proyek, merencanakan biaya proyek, merencanakan penjadwalan dan pengawasan proyek. Dengan susunan materi ajar tersebut peserta didik diharapkan mampu menerapkan keterampilan dan kecakapan yang menjadi profesinya, untuk menyikapi ikrar hidupnya dan mandiri karena memiliki suatu daya saing yaitu kemampuan merencanakan dan merancang suatu bangunan atau bagian dan materi ajar misalnya interior, desain furniture, pertamanan dan sebagainya.

Strategi proses pembelajaran dengan penekanan pendidikan luar sekolah ditekankan dengan penekanan pada kecakapan hidup berbasis kompetensi perencanaan dan perancangan bangunan. Materimateri yang diberikan disampaikan dengan metode yang berbedabeda, yaitu disesuaikan dengan jenis mata ajar yang diajarkan. Rencana pengajaran bersifat luwes dengan memperhatikan minat peserta didik yaitu menyesuaikan

Teori instruksional yang
baik adalah pengalaman
belajar melalui penemuan
(discovery) yang
memungkinkan peserta didik
memperoleh informasi dan
keterampilan-keterampilan
baru dengan memperhatikan
informasi dan ketrampilan
yang telah diberikan
sebelumnya.
tugas dengan minat dan pengalaman peserta didik sebelumnnya. Materi disajikan sedemikian sehingga menarik perhatian peserta dan mengikut-sertakan peserta didik secara interaktif. Instruktur pada proses pembelajaran tersebut dituntut untuk berfungsi sebagai pengelola proses belajar mengajar yang melaksanakan empat tugas, yaitu (1) merencanakan; (2) mengatur; (3) mengarahkan; dan (4) mengevaluasi. Secara keseluruhan materi diajarkan dengan menuntun peserta didik mengetahui, mengenali kemudian memahami halhal berkaitan dalam perencanaan dan perancangan bangunan, sehingga materi pengajaran dipecah-pecah menjadi unit-unit yang harus dikuasai teriebih dahulu oleh peserta didik sebelum melanjutkan ke materi berikutnya.

Hal ini dapat terlihat pada materi struktur dan konstruksi, pemahaman tentang gambar teknis bangunan, serta perencanaan dan perancangan bangunan harus dipahami terlebih dahulu oleh para peserta didik sehingga mereka dapat memahami tugas dan mampu mengerjakan tugas dalam studio perancangan bangunan. Dalam pemahaman materi maka penyusunan materi ajar disusun dari hal yang sederhana hingga ke hal yang lebih kompleks. Sehingga untuk catur wulan pertama arahan yang diberikan kepada peserta didik adalah mengenali, memahami, memecahkan masalah bangunan yang sifatnya masih sederhana. Secara prinsip perencanaan dan perancangannya memakai contoh proyek bangunan tempat tinggal dengan fungsi ganda, sistem struktur masih berlantai satu dan sederhana, tetapi gambar teknisnya tetap dilakukan sesuai standar untuk gambar teknis lapangan. Pada catur wulan kedua peserta didik dituntun untuk memahami dan memecahkan masalah yang lebih kompleks termasuk bagaimana mengalami suatu proyek bangunan yang lebih besar dengan struktur yang lebih rumit dan perencanaan dan perancangan bangunan lebih detil. Peserta didik dituntun untuk mengalami dan melihat di lapangan mulai dari melakukan survei, pendataan, pengukuran dan pengamatan mengenai halhal yang berhubungan dengan perencanaan dan perancangan bangunan. Hal ini sesuai dengan teori Bruner (Soekamto,1994) yaitu teori instruksional mengatakan bahwa pengalaman belajar melalui penemuan (discovery) yang memungkinkan peserta didik memperoleh informasi dan keterampilan-keterampilan baru dengan memperhatikan informasi dan keterampilan yang telah diberikan sebelumnya.

Pengalaman yang dialami oleh peserta didik ketika dalam proses belajar selalu ditekankan dan berhubungan dengan pengalaman yang sesungguhnya di kehidupan nyata. Pembelajaran di lapangan dilakukan pengarahan berbentuk tim kerja dengan besar kelompok sesuai dengan jumlah peserta didik. Peserta dibekali daftar dan urutan kerja serta tujuan pembelajaran dan materi yang harus dilakukan di lapangan. Peserta dikoordinasi oleh pemimpin tim yang dipilih oleh anggota tim dengan tanggung jawab per tim mengumpulkan berkas laporan yang akan digunakan sebagai bahan diskusi dalam pembelajaran di kelas.

Pembelajaran di kelas untuk pemahaman teori ini ada di materi perencanaaan dan peran-cangan dilakukan dengan simulasi untuk tim berupa pembagian 
tugas merencanakan suatu proyek yang berbeda-beda dalam satu kelas dengan beberapa tim. Dalam masingmasing tim peserta didik melakukan suatu diskusi mengenai deskripsi, tujuan proyek, dan desain yang berkaitan dengan proyek masing-masing.

Selanjutnya semua tim secara bergantian beradu argumentasi dan tanggapan serta kendala - kendala, kritik dan saran dalam sebuah simulasi diskusi panel, masing-masing tim berperan sebagai suatu konsultan yang menangani suatu proyek tertentu sedangkan tim lain yang hadir berperan sebagai calon penghuni/ pemilik proyek, wakil pemerintah, dan wakil masyarakat yang terkadang berperan sebagai pihak oposisi. Dalam pembelajaran ini pengajar / instruktur berperan sebagai moderator yang berperan sebagai mediator, penengah dan pengambil kesimpulan.

Hasil dari diskusi dikembangkan dalam perencanaan dan perancangan untuk proyek tugas tim selanjutnya sampai materi ajar perencanaan dan perancangan selesai. Di akhir pertemuan materi ajar perencanaan dan perancangan tim kembali diminta untuk presentasi karya berupa proyek yang dari sejak awal mereka rencanakan dan dikerjakan sebagai tugas kelompok. Presentasi berupa gambar rancangan , gambar kerja dan presentasi maket. Dalam hal ini materi ajar perencanaan dan perancangan tidak terlepas dari pemahaman peserta didik mengenai materi ajar yang lain yaitu pengetahuan struktural, pemahaman menggambar secara teknis, dan memahami perencanaan utilitas. Terlebih peserta didik dibekali kemampuan mempresentasikan gambar rancangan bangunan dalam aplikasi autocad, mampu menghitung dan merencanakan anggaran biaya bangunan, merencanakan syarat-syarat teknis bangunan, mengelola proyek, dan mampu menggunakan keterampilan perancangan interior.

\section{PEMBAHASAN}

Tinjauan studi kasus di atas merupakan suatu gambaran suatu proses pembelajaran yang tersusun dalam satuan mata ajar yang saling terkait sehingga proses belajar dimulai dari mempelajari hal dan masalah yang sederhana, dipelajari secara berturutan, kemudian berkesinambungan dengan materi ajar berikutnya untuk mempelajari dan memahami serta memecahkan masalah yang lebih kompleks.

Kurikulum disusun mengacu pada pengetahuan praktis yang berdasarkan situasi dan kondisi di lapangan sehingga materi ajar bersifat praktikal. Pengarahan teori terapan pembelajaran disesuaikan secara luwes sehingga peserta didik mampu mengikutinya. Teori selalu ditekankan kepada pemahaman dan pengalaman peserta didik dalam mengikuti materi ajar. Pengelolaan materi di kelas dan lapangan dengan sistem penugasan secara kelompok maupun pribadi. Penemuan masalah, penemuan cara memecahkan masalah kemudian menyusunnya dalam suatu bentuk terstruktur ditekankan dalam proses pembelajaran sehingga peserta didik tidak hanya mendapatkan teori tetapi ikut terlibat secara aktif untuk mengalami dan memperoleh pengalaman. Penciptaan iklim kompetitif di antara peserta pembelajaran dilakukan dengan metode pertemuan beradu argumentasi dan beradu prestasi tim kerja. Dengan iklim kompetitif peserta akan saling berusaha mengerjakan tugas lebih baik dari tim lain sehingga peserta didik akan lebih mudah mengukur kemampuan tim kerja maupun kemampuan pribadi. Dalam hal ini, peserta didik akan terlatih belajar mengelola, memimpin dan bekerjasama dalam tim kerja.

Pemilihan model belajar yang efektif dilakukan secara variatif, berbeda -beda disesesuaikan dengan materi ajar yang diberikan dan disesuaikan dengan metode model pembelajaran yang dipilih oleh masingmasing instruktur materi ajar yang terkait. Pemilihan model kerja kelompok dengan memberikan suatu tugas atau masalah khusus yang harus dipecahkan, menghasilkan suatu pemecahan dan membuat suatu pelaporan. Dalam model panel suatu permasalahan dikembangkan berbagai pandangan dari sisi yang bertentangan, peserta akan terlibat dalam suatu diskusi, sehingga instruktur akan berperan sebagai moderator yang mengambil kesimpulan terhadap permasalahan tersebut. Selain itu digunakan juga model penyajian situasi yang bertujuan membantu peserta menganalisis tindakan perseorangan atau kelompok dengan bermain peran, instruktur berperan sebagai komentator sehingga peserta mendapatkan informasi untuk berdiskusi.

Penyajian laporan dan konsep prarancangan serta dilengkapi gambar-gambar kerja dan maket dipresentasikan di hadapan instruktur dan penguji dari pelaku bisnis konstruksi mengkondisikan peserta berlatih berbicara di depan umum, mempertanggungjawabkan hasil karya dan bersikap profesional. 


\section{PENUTUP}

Pendidikan merupakan faktor penting dalam mendukung kebutuhan sumber daya manusia yang terlatih dan terdidik untuk menunjang perkembangan dan perubahan struktur ekonomi di dalam negeri. Lembaga Pendidikan harus menyesuaikan diri dengan perkembangan tuntutan kualitas sumber daya manusia dengan kemampuan serta penguasaan terhadap pendidikan kecakapan hidup sehingga meningkatkan daya saing serta kualitas sumber daya manusia.

Lembaga pendidikan perlu menyelenggara-kan suatu jenis pembelajaran yang sesuai dengan kebutuhan dalam masyarakat, dan memiliki nilai kompetitif dalam penyelenggaraan pendidikan dengan kompetensi sejenis melalui perencanaan inovasi sebagai perencanaan strategi dalam proses pembelajaran menggunakan metode dan model pengajaran yang tepat dan diterapkan secara luwes, serta kompetensi yang didapatkan peserta sungguhsungguh mampu diaplikasikan dalam kenyataan di lapangan.
Kemampuan yang didapatkan peserta tidak hanya skill yang bersifat terapan tetapi juga kemampuan pendukung yaitu kemampuan leadership, manajemen, dan kemampuan berkomunikasi dan interaksi secara sosial, peningkatan kualitas diri, kreativitas dengan kemampuan yang matang dibarengi rasa percaya diri yang ditumbuhkan melalui kemampuan-kemampuan soft skill menjadi daya saing bagi peserta didik selanjutnya dalam persaingan di dunia kerja.

Instruktur dengan pengalaman yang matang, kemampuan mengelola kelas dan seorang yang mempunyai jiwa sebagai motivator sangat diperlukan sebagai salah satu rencana strategis bagi penyelenggaraan pendidikan. Saran bagi pengelolaan suatu program kecakapan hidup melalui pendidikan hendaknya di masa-masa mendatang justru lebih dilengkapi dengan kemampuan berbahasa asing

\section{DAFTAR PUSTAKA}

Baskoro D.(1997). Life skill: konsep dan aplikasinya, Visi, Jurnal Media Kajian Pendidikan Luar Sekolah, 13/X. 2-20.

Pedoman penyelenggaraan program keterampilan hidup (life skill) pendidikan luar sekolah. (2003). Jakarta: Ditjen Diklusepa.
Soekamto, T. \& Winataputra, U. S. (1994). Teori belajar dan model-model pembelajaran. Jakarta: Dept. Pendidikan dan Kebudayaan, Ditjen Pendidikan Tinggi.

Supamo, P. (1997). Filsafat konstruktivisme dalam pendidikan.Yogyakarta: Kanisius. 